\title{
Perceptions of college students in Costa Rica about prostitution
}

\author{
Elizabeth Izaguirre ${ }^{1}$ \& Julián Monge-Nájera² \\ 1. St. Olaf College, 1500 Saint Olaf Ave Northfield, MN, 55057; izaguirr@stolaf.edu \\ 2. Programa de Patriarcado, Laboratorio de Ecología Urbana, UNED, 2050 San José, Costa Rica, jmonge@uned.ac.cr; julianmonge@gmail.com \\ Recibido 20-VIII-2015 • Corregido 20-X-2015 • Aceptado 11-XI-2015
}

\begin{abstract}
The view that college students have about prostitution is poorly known, and the little research that is available has been done in the USA and Spain. To study the perceptions and knowledge of college students about prostitution in Costa Rica, we interviewed sex workers, directors of foundations and 200 students from San José and Puntarenas, Costa Rica. Most students have a fairly realistic view of the phenomenon; most believe that people enter sex work through a combination of need and choice, that sex abuse is not inherent, that most sex workers have families to take care of with limited education. In regards to the clients most students believe the majority are varied in age, tend to have families and often become regulars. Our results are similar to those reported for Spain.
\end{abstract}

Key words: Sex work, sex trafficking, how media present prostitution, reality versus fiction, college students.
RESUMEN: En Costa Rica, la mayoría de los periodistas que escriben sobre el trabajo sexual son hombres que lo ven como algo criminal y inmoral, y por lo general no entrevistan a los trabajadores del sexo. Para evaluar si el tratamiento mediático del tema se refleja en la percepción y el conocimiento de los estudiantes universitarios, entrevistamos a trabajadoras del sexo, directoras de fundaciones y 200 estudiantes. Los estudiantes tienen una visión realista del fenómeno: la mayoría cree que la gente entra en el trabajo sexual a través de una combinación de necesidad y la elección; que el abuso sexual no causa que lo hagan; que la mayoría de las trabajadoras sexuales tienen familias que cuidar pero sufren de una educación limitada, y que sus clientes son variados en edad, tienden a tener familia y con frecuencia se vuelven clientes fijos. Todas estas opiniones están de acuerdo con los informes científicos sobre el tema y sugieren que los estudiantes aprenden sobre prostitución de fuentes adicionales a los medios de comunicación tradicionales.

Palabras clave: Trabajo sexual, tráfico sexual, cómo presentan los medios la prostitución, realidad frente a la ficción, estudiantes universitarios.
The exchange of sexual activities for resources (mostly but not exclusively in the form of money) has long been a taboo subject in scientific research (Whelehen, 2001). Currently some variants of this phenomenom are identified as sex work, while the derogatory word "prostitution" is rejected by some, including people who practice it. There are also multiple ideas about its origin, the most recent in the field of sociobiology which reports that females of several species (including bonobos, chimpanzees and humans) exchange sex for resources necessary for themselves and for their offspring, and that both males and females can provide the sex or the payment in these transactions, depending on the circumstances (Parish, 1994; Monge-Nájera, Campos, Bonilla \& Ramírez, 2009).

This controversial topic is viewed differently in every country, every city, and by every person, resulting in different laws and safety measures for the people in the sex industry. These differences in law also cause the culture and perceptions to be different in every community. Historically, the act of prostitution goes back to ancient times and was even used as a sacred practice in the temples of Ancient Babylon and Sumer (Frazer, 1922; Dillon \& Garland, 2005). In some countries there is a debate about the legal status of prostitution; some believe that legalization regulates working conditions and maintains equal rights for women (Brown, 2014). The opposing side believes it should be criminalized, also with arguments of equal rights, morality, prevention of trafficking and reduction of disease (Downe, 1999). RiversMoore (2014) suggested that the issue of sex trafficking should be considered a form of labor trafficking. In any industry where there is high demand and a chance for profit, there is space for exploitation. This can make it 
difficult for people to distinguish between sex trafficking and prostitution which can lead to misconceptions and debates about which implies equal human rights: legalizing prostitution for the rights of the workers, or criminalizing it in an attempt to reduce human slavery. However, if one can look at the two as separate entities, both sides will benefit (Rivers-Moore, 2014).

The lack of attention and societal assumptions create dangerous working conditions for voluntary sex workers. These women are forced by society into harsh economic conditions, resort to sex work and end up getting stigmatized without considering that society put them there in the first place (Ramírez-Sánchez, Monge-Nájera, RojasCampos \& Morales, 2009).

In the particular case of Costa Rica, prostitution is legal for the workers but not for those "promoting or facilitating" it. A big emphasis on Costa Rica's sex tourism and child exploitation scene has caused alarm in other countries, and has raised the question of trafficking. However, several studies have reported that most female and male sex workers freely choose this line of activity and work as independent contractors (Rivers-Moore, 2009, 2010, 2013, 2014).

The only study about how the media treat sex workers in Costa Rica found that most reporters who write about sex work are men who see it as criminal and inmoral, and that usually the sex workers themselves are not interviewed for reports that directly affect them (MongeNájera, Corrales \&, 2013).

In this study, the perceptions and knowledge of college students were studied in the capital and in a small coastal city.

\section{METHODS}

Our data are from private and public universities in two contrasting Costa Rican cities, San José and Puntarenas, where sex tourism concentrates (U.S. Department of State, 2012). San José (300 000 inhabitants) is the capital, ranked as one of the fastest growing and sixth most important destination city in Latin America, indicating high levels of tourism (MasterCard, 2014). Puntarenas (36,650 inhabitants), once known as one of the biggest coffee export ports in the world, is now in impoverished port with a small commercial fishing fleet and a budding local and cruise-line tourist industry (DS-Lands, 2014).

The main author interviewed students of the largest public university in the country (University of Costa Rica, UCR: San José and Puntarenas campuses), and of two private institutions: Universidad Latina (San José), and Universidad Hispanoamericana (Puntarenas).

Our methods and questions were inspired by Morton, Klein \& Gorzalka (2012). Questionnaires included 31 multiple choice and three optional, open-ended questions about perceptions and opinions of sex work (Digital Appendix 1). College students were chosen specifically as a safer method for collecting data, as opposed to strangers on the street, and because college students tend to be a more uninhibited population. Participants were approached through convenience sampling in public areas of each campus and in some classrooms with the permission of the professor.

Participating numbers are as follows: San José 70 UCR and $38 \mathrm{U}$. Latina; Puntarenas: 70 students per university. Participants were told that the first author was an exchange student doing research and the questionnaire was voluntary, and that they could stop whenever they wanted or skip any questions they chose not to answer. They were not asked to disclose any distinguishing information.

Additionally four interviews were conducted: the directors of Fundación Procal and Fundación Rahab, and two group interviews with 12 women associated with "La Sala," ranging in ages from 26 through 68 . Procal offers workshops, classes, and social action for underrepresented groups in society, and Rahab offers classes, support groups, and employment for survivors of sex trafficking. La Sala provides female sex workers with a support group and classes on safe practices. Interviews were conducted in concordance with the questionnaires, to compare between opinions of students and experts. Interview I at La Sala was preliminary and used to establish comfortable relations. During interview II, women were directly asked each question on the questionnaire and asked to give their opinions on the realities of the life as a sex worker.

The study and methods for protection of human research subjects was approved by the ACM Ethics Panel.

\section{Analysis}

The questionnaire used the word "prostitution," however, after interviewing the women in La Sala, "sex work" was the preferred term when talking to them. The term "prostitution" is used in this article to keep consistency in describing the results and discussion. Strength of dependencies of levels of attributes (gender, where they grew up, religion, scholarship, and whether or not they grew up with two parents) on various questionnaire questions were estimated by Contingency Tables. Differences in mean responses to questions \#22 and \#24 and were estimated by parametric one-way ANOVA. Statistical 
procedures followed Sokal and Rohlf (1995) and were done with Statgraphics Centurion XV Ver. 15 (Statpoint Technologies, Inc., Statgraphics.com).

\section{RESULTS}

\section{Demographics Summary}

A total of 200 questionnaires were answered. Ninety percent of the students grew up with siblings and about 75\% were between the ages of 17-21 (detailed statistical results in Digital Appendix 2).

\section{Stereotypes vs. Reality}

Most students (90\%) did not think that sex work was an uncomfortable topic, and about $90 \%$ did not know or responded "no" when asked if they thought domestic violence would increase if prostitution were outlawed ("La Sala" women and one foundation director answered "yes"). While 52\% did not agree with prostitution, $45 \%$ considered it a valid form of work. When asked about a typical person in prostitution, $91 \%$ believed the activity was a combination of necessity and option. Around $75 \%$ of students believed that the less education a worker has, the more susceptible they are to enter sex work.

Approximately $69 \%$ of students believed that people in prostitution have families. All the women in "La Sala" said they had chosen their job out of necessity and they did not have many other options. One stated that she went into the sex industry because "she had to do something" to live. All but the youngest worker said they had children to take care of, but none of them had a spouse. One foundation director said that for some people, especially for some of the younger women, it is more of a rebellious choice or a result of the rising "it's your body, you can do what you want with it" culture. The other director said "People enter for many reasons, like to get drugs or other resources, because these women aren't able to get these resources on their own." She added that it was common for people to enter through a network, so a friend or family member may suggest it and then it gets snowballed. It was revealed during each interview that although historically people turn to prostitution for lack of a better job, the population of sex workers with more opportunities, such as college students, is rising.

Nearly half the students (55\%) believed that drug addiction is a problem amongst people in prostitution, and slightly less believed in the prevalence of STDs amongst workers (38\%). The women in "La Sala" responded that sex workers are not more likely to be addicted to drugs or have an STD than the average woman. Most said they had never taken hard drugs but knew women had become addicted. One director said that most of the women she has worked with have had a drug problem. Women in La Sala said that they have worked hard on prevention of HIV in their organization and it is no longer a problem for them, but that this in turn caused NGOs to eliminate the support they enjoyed a few years ago. Both directors said that sex workers are at a higher risk, but do not necessarily have a higher prevalence of disease. Only $17 \%$ of students believed that the majority of sex workers suffered from child abuse. When women in "La Sala" were asked if they thought the majority of sex workers had experienced child abuse, they said it could be true but it is not something they normally discuss. They did not necessarily believe that a sex worker is more likely to have that kind of past than anyone else.

When asked about clients, only $29 \%$ of students believed that there was a typical age for them. About $88 \%$ believed that clients return, $87 \%$ that clients had families, and $59 \%$ that the majority of clients are rich. According to the women in "La Sala," there are clients of every age; adding that older men tend to request younger women and viceversa. They added that the majority of clients are married and return for their services after the first experience. Some of the women said they have had very loyal customers, although their wealth varies and men who buy their services are not always rich.

\section{Crosstabulations of Demographics and Student Opinions}

Richer and social science students supported the legalization of sex work, while poorer students, declared Christians and bussiness students, rejected it $(X 2=14,463$; $\mathrm{df}=2 ; \mathrm{P}=0,001 ; \mathrm{X} 2=18,598 ; \mathrm{df}=2 ; \mathrm{P}<0,000 ; \mathrm{X} 2=24,299$; $d f=8 ; P=0,002$ ).

Those majoring in a social science $(X 2=20,792 ; \mathrm{df}=8$; $\mathrm{P}=0,008)$ or receiving financial help through scholarship ( $X 2=9,442 ; d f=2 ; P=0,009)$ considered it a valid form of work. Christians and women tended to say "no" ( $\mathrm{X} 2=$ $20,525 ; d f=2 ; P<0,000 ; X 2=16,159 ; d f=6 ; P=0,013)$.

Students majoring in a social science $(X 2=23,369$; $d f=12 ; P=0,045)$ and Christians $(X 2=9,757 ; d f=3 ; P=0,021)$ said that people entered prostitution out of "necessity". Those coming from urban areas tended to rate human trafficking as a bigger problem $(\mathrm{X} 2=13,02 ; \mathrm{df}=2$; $\mathrm{P}<0,0001)$. 


\section{DISCUSSION}

There seems to be a low number of articles of this subject, which makes a contextual discussion of our results more difficult. Four related studies dealt with college students' view of sex work and their education on the subject. In a small sample of American college students, Basow and Campanile (1990) found that the students had a generally negative view of sex work and that this negative view was even stronger among female students. Another study asked undergraduates if they knew students doing sex work and found that they believed sex workers had poor psychological well-being, drinking problems, hard financial circumstances and a history of sexual abuse (Roberts, Bergström \& La Rooy, 2007). Finally, a study on the education of social workers reported that those students received few courses preparing them to understand and respond to the needs of sex workers (Francis, 2015). Costa Rican students are only slightly more sympathetic towards such people. The study most similar to ours is one by De las Heras, Barahona, García \& Corchado (2006) about the attitude of students about female sex work in Spain, which found effects of gender and social background on students' perceptions and understandings of sex work.

Our data indicate that most students have a fairly realistic view of the phenomenon when compared to the answers provided by "La Sala." Most believe that people enter sex work through a combination of need and choice, that sex abuse is not inherent, and that most sex workers have families to take care of with limited education. and that clients are varied in age, tend to have families and often become regulars. There seems to be a regional cultural difference in how students perceive sex work; results are similar to those of another Latin, Catholic country (as described by De las Heras et al., 2006) than to those of Protestant, Anglosaxon contexts as reported by several authors (i.e. Basow and Campanile, 1990; Roberts, et al., 2007; Francis, 2015).

On the other hand, the belief that sex workers are significant vectors of sexual disease, held by $38 \%$ of the Costa Rican students in our study, is incorrect and may reflect the wrong view presented by the media (e.g. Monge Nájera et al., 2013). On this respect, Costa Rican students seem to be as ill informed as their Anglosaxon counterparts as reported by Roberts, et al. (2007) and Francis (2015).

Similar findings were reported by De las Heras et al. (2006) on the basis of a study they made in a Spanish University in 2005.
It is harder to explain why students lacking a scholarship, who tend to have a better financial condition and might be expected to be more conservative, support legalization.

Having a better understanding of the culture surrounding the sex industry in Costa Rica should provide necessary information for further research and comparisons between countries. The results of our study also suggest how to further protect the rights and lives of sex workers. If we can distinguish between sex work and sex trafficking, we can focus on removing the stigma from prostitution, and in turn make it easier to help anyone wishing to leave it.

\section{ACKNOWLEDGEMENTS}

We thank Andrea Anfossi and Bonnie Furman for their support and advice, Michael McCoy for support with planning and analyzing, Daniel Rojas for allowing questionnaires in his classroom, and Nicole Soto and Oscar Mo (UCR) for help with questionnaires. A special thanks goes to the interviewed women for their time and honesty.

\section{REFERENCES}

Basow, S. A., \& Campanile, F. (1990). Attitudes toward prostitution as a function of attitudes toward feminism in college students: An exploratory study. Psychology of Women Quarterly, 14, p.135-141.

Brown, E. N. (2014). What the Swedish model gets wrong about prostitution. Time. Retrieved from: http:// time.com/3005687/what-the-swedish-model-getswrong-about-prostitution/

De las Heras, M. V., Barahona, M. J., García, L. \& Corchado, A. (2006). Estudio sobre la opinión y actitud de estudiantes universitarios sobre el fenómeno de la prostitución femenina. Universidad Complutense de Madrid. Revista Acciones e investigaciones sociales. N. Extraordinario 1, 182. Recuperado de la web el 19 de agosto de 2015 en http://dialnet.unirioja.es/servlet/ articulo?codigo $=2002307$

Dillon, M. \& Garland, L. (2005). Ancient Rome: From the early republic to the assassination of Julius Caesar. Routledge.

Downe, P. J. (1999). Laughing when it hurts: Humor and violence in the lives of Costa Rican prostitutes. Women's Studies International Forum, 22 (1), 63-78.

DS-Lands. (2014). DS World's Lands. Available from: http://ds-lands.com/lt/C/ 
Francis, H. (2015). Educating Students About the Social Constructs of Sex Work: Integrating a Course Focused on Prostitution into the Social Work Curriculum. Doctorate in Social Work Dissertation, University of Pennsylvania, Philadelphia, Pennsylvania.

Frazer, J. G., Sir. (1922). The Golden Bough. New York: Macmillan.

MasterCard (2014). 2014 Global Destination Cities Index. Retrieved from: http://newsroom.mastercard.com/wpcontent/uploads/2014/07/Mastercard_GDCl_2014_ Letter_Final_70814.pdf

Monge-Nájera, J., Campos, R. R., Bonilla, R. M. \& Ramirez, I. A. (2009).Trabajo sexual femenino en la ciudad de San José, Costa Rica: Un enfoque sociobiológico al iniciarse el siglo XXI. Cuadernos de Investigación UNED, $1(1), 27-31$.

Monge-Nájera, J., Corrales, K. V., \& Lutz, M. I. G. (2013). Presentation of sex work in two Costa Rican newspapers: A multivariate analysis of the roles of patriarchal prejudice and reporter gender. Cuadernos de investigación UNED, 5(2), 325-331.

Morton, H., Klein, C., \& Gorzalka, B. B. (2012). Attitudes, beliefs, and knowledge of prostitution and the law in Canada. Canadian Journal of Criminology and Criminal Justice, 54 (2), 229-244.

Parish, AR. (1994). Sex and food control in the "uncommon chimpanzee": How Bonobo females overcome a phylogenetic legacy of male dominance. Ethology and Sociobiology, 15 (3), 157-179.

Ramírez-Sánchez, I., Monge-Nájera, J., Rojas-Campos, R., \& Morales Bonilla, R. (2009). La escolaridad en trabajadoras sexuales de la ciudad de San José, Costa Rica, al iniciarse el siglo XXI. Cuadernos de Investigación UNED, 1(1), 33-42.

Rivers-Moore M. (2009). Getting ahead in gringo gulch: transnational sex tourism in Costa Rica. Doctor of philosophy Dissertation. University of Cambridge.

Rivers-Moore M. (2010). But the kids are okay: motherhood, consumption and sex work in neo-liberal Latin America. British Journal of Sociology, 61(4), 716-736.

Rivers-Moore M. (2013a). Affective sex: Beauty, race and nation in the sex industry. Feminist Theory, 14(2), 153-169

Rivers-Moore M. (2013b). Imagining Others: Sex, Race, and Power in Transnational Sex Tourism. ACME, 10 (3), 392-411

Rivers-Moore, M. (2014). But what about trafficking? Border Criminologies. Retrieved from: http://bordercriminologies.law.ox.ac.uk/but-what-about-trafficking

Roberts, R., Bergström, S., \& La Rooy, D. (2007). Sex work and students: an exploratory study. Journal of Further and Higher Education, 31 (4), 323-334

Sokal, R. R., \& Rohlf, F. J. (1995). Biometry: The principles and practices of statistics in biological research. New York: W. H. Freeman.

U.S. Department of State: Diplomacy in Action (2012). Country Narratives: Countries A Through F. Retrieved from: http://www.state.gov/j/tip/rls/tiprpt/2012/192366.htm

Whelehan, P. (2001). An anthropological perspective on prostitution: The world's oldest profession. Lewiston, N.Y: Edwin Mellen Press. 
